\title{
The Fundamental Rights of States in Neoliberal Times
}

\author{
Sahib Singh*
}

\begin{abstract}
This is a critical introduction to the special issue on the fundamental rights of states. Whether such rights exist, the bounds of their existence, or whether they ought to be striven towards are questions of considerable import in the wake of the Greek sovereign debt crisis, or even given the ongoing Palestinian struggle for permanent sovereignty over their natural resources. I briefly outline how we might consider the question: is there any progressive political value in buttressing the state and its autonomy, through the doctrine of fundamental rights, in today's neoliberal world? First, I examine how we may progressively look at fundamental rights-as doctrine, narrative, memory or discourse. Second, I question the extent to which it is useful to see competing subjectivities, ie the maligned state against technocratic institutions, in a time where neoliberal logic has come to structure the workings of the state. It becomes quickly apparent that the discourse of fundamental rights may be used to both resist neoliberalism and enable it.
\end{abstract}

\section{Keywords}

Fundamental Rights of States, Neoliberalism, Resistance

We should not speak solely of the doctrine of the fundamental rights of states. To insist on such a reduction is to do a disservice to a topic that goes to the heart of international law. This critical introduction to the special issue seeks to broaden the lens with which we may view the subject-matter, urging international lawyers to grasp both the difficult and penetrating questions it unearths as well as their contemporary relevance.

What is the nature of the state? What characteristics or capacities, if any, inhere in the very designation 'state'? Is it possible to speak of the 'fundamental rights of states' as strictly legal rights, or is there normative value in seeing it as some other form of legal discourse? What precise notion of order does 'fundamental' entail or what character

* Post-doctoral Research Fellow, Erik Castrén Institute of International Law and Human Rights, University of Helsinki (Finland). Many thanks to Luca Bonadiman, Paavo Kotiaho and Jean d'Aspremont for their comments. This symposium owes a great deal to the work and organisation of Daniel H Joyner, Marco Roscini and Jean d'Aspremont, the discussions that took place at the University of Alabama School of Law in early 2015, and the intellectual tenacity with which each author approached this collective endeavourmy thanks go out to each one of them. 
does this ascribe to the rights themselves? How does the doctrine relate to the weakened autonomy of the state in today's geopolitical landscape? The subject of this special issue presupposes and presents answers to some of these questions, whilst urging us to confront others. From my own perspective there is a key question that brings the topic of fundamental rights of states to contemporary relevance. It is this: is there any political value in buttressing the state and its autonomy, through the doctrine of fundamental rights, in today's neoliberal world?

The state is apparently ailing. Late twentieth century thought in economic, political and legal fields announced its demise. Not to mention that within each field, strands of thought spanning back over two centuries or more have advocated for said demise, if not the state's outright abolition. Contemporarily, it was assailed from the political right by free market ideology and significant challenges to its relative authority by neoliberal international institutions. From the political left, 'progressive' voices continue to be animated by a sentiment articulated by Nietzsche: 'State is the name of the coldest of all cold monsters. It even lies coldly, and this lie crawls out of its mouth: "I, the state, am the people." This is a lie! ${ }^{1}$ It is a thought that has driven important research across social, political, economic and legal fields, all the while intellectually undoing the state's

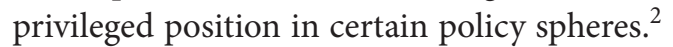

No doubt, these broad intellectual trends have helped undermine the autonomy and political authority of the state. But both trends encourage an underlying intellectual stance of functionalism. Here, the state is seen as only one actor or mechanism through which the obligations and functions of the state can be fulfilled. Where the state fails, one can defer to the international community or to the market (or to private actors, etc) to fulfil its requisite functions. ${ }^{3}$ The state becomes instrumentalised-and sees (and at times, willingly embraces) itself this way-for the fulfilment of particular interests and in the process is reduced to being as much use as any other actor or mechanism. In the words of the political theorist Wendy Brown: '[T]he state must not simply concern itself with the market but think and behave like a market actor across all of its functions, including law. ${ }^{4}$ There is no longer any value that inheres in its capacity to represent diverse groups of peoples, or the manner in which it may conduct this representation. Indeed, the state's capacity to conduct this 'representation' has become seriously curtailed. It is this transformation of the state that goes to the heart of the matter. So often, and correctly, considered an oppressor of its 'peoples', it is of little surprise that it has been undone as a potential bulwark against forms of oppression imposed by unaccountable

1 Friedrich Nietzsche, Thus Spoke Zarathustra (Adrian del Caro and Robert Pippin eds, Adrian del Caro tr, CUP 2006) 34.

2 For an overview in international legal thought, see Oscar Schachter, 'The Decline of the Nation-State and its Implications for International Law’ (1998) 36 Columbia J Transnatl L 7.

3 For a recent exploration of this established theme in international legal thought, see Anne Orford, 'Constituting Order' in James Crawford and Martti Koskenniemi (eds), The Cambridge Companion to International Law (CUP 2012) 271.

4 Wendy Brown, 'Neoliberalism and the End of Liberal Democracy' in Wendy Brown (ed), Edgework: Critical Essays on Knowledge and Politics (Princeton UP 2005) 42 (emphasis in original). 
international economic institutions or private actors. It is this situation that must be changed.

I do not argue that there is any inherent value in sustaining the state's autonomy. If anything, such advocacy is the precise juncture at which, as history has taught us, healthy scepticism is necessary. Rather, I tentatively suggest that hand in hand with such scepticism, it may be politically progressive and necessary in today's neoliberal world to find strategic ways in which to buttress the state's autonomy, and hence its political authority. This position is founded on three beliefs. First, that the state may offer greater accountability, participation and processes allowing for change for today's citizens, if contrasted with the technocracy that governs today's international economic and public institutions. Second, that if given the correct tools, it may possibly act as a barricade against greater and perhaps more normalised forms of oppression found in some of today's international institutions. I return to these first two beliefs below. And third, that it is the task of legal thought to change the status quo. Not merely to describe it or to evaluate it. The duty of the legal scholar does not lie in positive legal inquiry, but rather to look for spaces for contestation and transformation, whilst not over-determining or under-determining these spaces.

It is with these considerations in mind that we come to the legal discourse of the fundamental rights of states. I have chosen to speak of our subject matter as a legal discourse rather than doctrine for both theoretical and historical reasons. As a matter of theory, international law's normative authority is not strictly and solely limited to and vested in its 'rules' or 'norms'. Rules - whether rights, duties, secondary or primary, specific or of general applicability-may be the main currency for international law's normative authority. But they are almost certainly not its only source. It is possible to speak international law in the language of standards and principles. Think of the tired debate regarding soft law, just as large swathes of the field have become established, defined and continue to proliferate with this often vitiatingly vague form of regulation. Here, international law's normative authority is not strictly officiated in the form of an on/off switch. ${ }^{5}$ This anti-positivist theoretical stance-namely, the belief that it is possible to speak international law with a degree of normative authority without speaking of strictly legal rules or norms-is further supported by historical practice in the sphere of the fundamental rights of states.

When Ricardo Alfaro gave his Hague Academy lecture in 1959, he noted how specific 'fundamental liberties ${ }^{6}$ were called 'attributes, qualities, competencies, powers, norms or rights. ${ }^{7}$ Up to and beyond this historical juncture, the discourse of fundamental liberties had provided protective umbrage to a number of states that sat at international law's margins (particularly inter-American states) despite-and possibly because of - its vague,

5 See further Sahib Singh, 'Narrative and Theory: Formalism's Recurrent Return' (2013) 84 BYBIL 304, 334-36.

6 I borrow this from Stephen C Neff, 'The Dormancy, Rise and Decline of Fundamental Liberties of States' (2015) 4 CJICL 482.

7 Ricardo J Alfaro, 'The Rights and Duties of States' (1959) II Recueil des Cours 116. 
general and indeterminate conceptual character. In the 1930s and late-1940s, there were attempts to develop a positive legal doctrine, attempts that were again taken up postdecolonisation in the 1960s and 1970s. But as both Jean d'Aspremont and Stephen Neff note in this symposium, the protective function and capacity of the discourse was all but 'annihilated' in these attempts to delimit and squeeze it into positive form. In short, the normative legal authority and politically progressive capacity of the fundamental rights of states lay in its discursive flexibility, and its capacity to tap into a political understanding of rights within legal frameworks. ${ }^{8}$

And yet, some contemporary international lawyers are far from optimistic about the contemporary political possibilities of fundamental rights discourse. Antonios Tzanakopoulos, in this special issue, relates the doctrine to the Greek sovereign debt crisis. He demonstrates that there is no positive right, let alone fundamental right, to be free from economic coercion, nor any doctrine of fundamental rights of states in any meaningful sense." Therefore, he concludes that the legal doctrine-and the specific rights it may encompass - is of no political relevance to the Greek sovereign debt crisis and the developments that have occurred this year. Rather, 'the way to cure the world of this ill is politics, political struggle in particular. Politics can establish fundamental rights of states as a legal category; political struggle can change the law. ${ }^{10}$ For Tzanakopoulos, law can only speak when there is a determinate, positive legal norm that can be identified and posited against another actor. Law only carries normative authority in the form of a legal rule, norm, or in this case, right. And we can only use law to engage in political struggle once it has adopted this strict form, for without it law is incapable, powerless and normatively inert. And in this understanding, politics is cast outside the law-first, before the law (creating it) or under it (where law, once created, can speak to power). For Tzanakopoulos, the 'discussion of fundamental rights of states thus should not be seen as some independent legal category, but at best as an argumentative practice or as a narrative of resistance. ${ }^{11}$ Not only is there no place for progressive political struggle within the law, enmeshed into the very fabric of how we may speak it, but there is the declaration that, in this context, law cannot speak or be spoken. Not only does this approach suffer from historical amnesia, but it also sustains an ideological approach to law that embeds the status quo, forcing the international lawyer towards resigned passivity.

That the inter-American states in the early 1930s and throughout the mid-to-late 1940s and decolonised states in the 1960s and mid-1970s chose to speak the language of fundamental rights of states in a politico-legal discourse-both strategic and argumentatively legal-is beyond doubt. ${ }^{12}$ But even if we learn this historical lesson, and

8 Jean d'Aspremont, 'The Doctrine of Fundamental Rights of States and Anthropomorphic Thinking in International Law' (2015) 4 CJICL 501; Neff (n 6).

9 Antonios Tzanakopoulos, 'The Right to be Free from Economic Coercion' (2015) 4 CJICL 616, 633.

10 ibid.

11 ibid (emphasis added).

12 See, generally, International Law Commission, 'Preparatory Study Concerning a Draft Declaration on the Rights and Duties of States-Memorandum submitted by the Secretary General' (15 December 1948) 
the discourse of fundamental rights can be seen as a legal ground from which political struggle may be waged, it does not answer how this discourse may fare in our neoliberal times. Nor should it enshrine an a-critical willingness to support this legal discourse. Even if states can speak in this legal discourse-with its attendant rights, principles, or standards-for what particular purpose, against whom and how is it deployed? In the context of Greece and other states within Europe receiving forms of shock therapy this discourse may be used as a form of resistance against the European Central Bank, the International Monetary Fund and the European Commission. But even if it may, in the abstract, allow Greece to speak a legal discourse of resistance, it may also allow other, competing actors to shape the ecosystem in which this speech is rendered inconsequential. A discourse of resistance can, in other's hands, enable repression. Think here of the total disregard for human rights obligations within the same context of Greece; ${ }^{13}$ the existence of a right does not render it consequential. In the context of the fundamental rights of states, the very same observation can be made; that we can speak through a legalpolitical discourse does not necessarily mean that this discourse has purchase.

If this is one way to frame the role of the fundamental rights of states in today's neoliberal times, another way has been alluded to above. Namely, as a legal discourse that may be used to buttress the state and its autonomy against the intrusive political authority of technocratic international institutions. The logical, and political, premise of this frame is that it provides a choice between two competing subject-types and subjectivities; between two different ways of organising the social. The assumption is that in our neoliberal times we ought to provide protective umbrage to the maligned Hegelian state-the one that may represent its people. If the legal discourse of fundamental rights can aid in this venture, then it may be used as a tool for resistance; deployed by the state, through the state, against the hegemony of neoliberal institutions. But this frame and narrative may over-determine the space for resistance, especially for powerless states and any solidarity that may exist between such states.

What if we are to understand neoliberalism as a material political rationality? If it is no longer purely an economic rationality concretised in the Bretton Woods institutions and their successors, but is rather supported, sustained and emboldened by the state? What if we understand the market as no longer controlled by the state, but rather as having become the organising principle of the state? Surely then, to buttress the state's autonomy would be a futile gesture. What if we accept Wendy Brown's contention that 'the health and growth of the economy is the basis of state legitimacy?'14 These sets of questions turn the logical frame in the previous paragraph on its head.

The political stance no longer becomes one of supporting competing subjects and their subjectivities, ie the maligned state against technocratic institutions. The

UN Doc A/CN.4/2, 5-9; (24 October 1970) UN Doc A/RES/25/2625; (17 December 1973) UN Doc A/ RES/28/3171.

13 See Margot Salomon, 'Europe's Debt to Greece' (EJIL: Talk!, 24 August 2015) <http://www.ejiltalk.org/ europes-debt-to-greece/> accessed 28 October 2015.

14 Brown (n 4) 42. 
question that becomes key to progressive politics is: how far has neoliberalism eroded the democratic state? If you believe that the Hegelian state has entirely perished in neoliberalism, then to buttress the state would not only be folly, but it would enable the very forms of repression that one may have sought to challenge. From this perspective, the legal discourse of the fundamental rights of states no longer appears to be a space for dissent or transformation. Rather, this legal discourse may simply become another set of regulative principles that are likely to be subordinated to an economic rationality and instrumentalised by a state that marches in service to the market. However, if you believe, as I do, that the state may retain an ability to represent its diversity of peoples and shape the social through its mechanisms of liberal democracy, there remains resistive and political potential in buttressing it. The legal discourse on the fundamental rights of states-depending on how it is used, by whom and against whom-may in certain contexts be useful for various forms of transformative politics.

The task of the international lawyer has now become considerably murkier. The legal discourse of fundamental liberties may be used to both resist neoliberalism and enable it. It may be used to strengthen the state. But which contemporary idea of the state is it strengthening? The international lawyer in their pursuit of transformative politics may be required to tread along the psychological lines of Susan Marks' usage of Harold Bloom's 'the anxiety of influence. ${ }^{15}$ It is not out of simple fear of irrelevance that we try and make the legal discourse of fundamental rights relevant to contemporary political issues, but that in this very act that we realise that this legal discourse and other legal discourses may be complicit in the very politics that we are trying to resist.

This critical introduction has sought to be suggestive of inquiry, aiming to provide certain framework considerations. Even if one is pessimistic about the existence of specific fundamental rights of states, as precisely that-fundamental rights-there is no doubt value in understanding them as a form of legal discourse. Whether its vitality can be used against neoliberal political and economic thought is one of the more pressing questions that one can pose. I have attempted to show that, whilst promising, this line of inquiry is anything but easy. But this is merely one of many contexts in which the question of fundamental rights is of contemporary relevance. Think quickly of the Palestinian state and the right to permanent sovereignty over its natural resources and its right to non-interference; think of Iran and the right to peaceful use of its nuclear energy, think of Israel and its right to existence. This handful of examples does not do the vibrancy of the topic justice. The papers that follow are not only doctrinally useful, contemporarily relevant and necessary, but also rooted in some of the more interesting questions that go to the heart and structure of our field. 